\title{
"I Fear not Wave nor Wind": Aspects of Fibich's Journey toward Modern Music
}

\author{
Judith Fiehler
}

Fibich's contemporary Josef Foerster, who knew Fibich and understood his music in the context of its era, remarked: "Fibich's entire life was a pilgrimage for the sake of beauty." ${ }^{1}$ But there is also something Byronic in Fibich's fearless search for the heights and depths of noble dramatic utterance, for the boundaries of art. The title of this paper refers to Byron's poem Childe Harold's Pilgrimage. Fibich's pilgrimage, like Childe Harold's, sometimes led in unexpected directions. Paradoxically, the principles of Classic art as they were perceived in his time brought him to the threshold of modernism.

Fibich had the good fortune to study privately in Leipzig with one of the best theorists of the Romantic era: Salomon Jadassohn, piano student of Liszt as well as the Pragueborn virtuoso Ignaz Moscheles. Jadassohn fully adhered to the Leipzig ideals of Romantic Classicism, but was first of all a composer. He supports his ideas with insightful musical analyses, usually taken from Bach and the Romantic composers from Beethoven to Schumann. George Chadwick, an outstanding American composer and teacher of composers, also studied with Jadassohn. Thus it is not surprising that Chadwick's works from the 1890s are sometimes reminiscent of Fibich's music. As director of the New England Conservatory, Chadwick was instrumental in establishing a vital tradition for American music that combined the strengths of Classicism with the expressivity of Romanticism. This tradition culminated in the 1960s with the distinguished symphonies of William Schumann and Walter Piston.

Perhaps to ensure that the Classicist spirit would endure, aestheticians such as Eduard Hanslick sought to define it logically-as it were, to write specifications for art still to be created-taking it for granted that artistic genius would take care of itself. Many of Fibich's contemporaries, artists as well as musicians, felt that the resulting constraints were so oppressive that it was almost impossible to go forward. But Fibich had developed a sense

1 “Celý život Fibichův byl pout za krásou.”, in: Josef Foerster, Co život dal [What Life Gave] (Prague, 1942), p. 36. 
of the greatness of art as well as a strong creative instinct under the influence of the early Romantics, and perhaps for this reason he was able to evolve instead of conforming or rebelling.

The Leipzig tradition, inspired by the genius of Goethe, gives us clues to Fibich's approach. Goethe, the author of the texts of many songs from Fibich's youth, ${ }^{2}$ was the very embodiment of a natural union of aesthetics, philosophy, art, and human experience. However, he preferred Carl Friedrich Zelter's rather simple settings of his poems to Schubert's much more famous versions. Paul Henry Lang commented: "But does that not rather imply that Goethe felt that while his verse still dominates Zelter's song, Schubert would turn it wholly into music, thereby robbing the poet of his own property?"3 Mendelssohn, Leipzig's leading composer, was Goethe's protégé and Zelter's student as well as the close friend of Moscheles. Mendelssohn's incidental music for plays by Shakespeare, Sophocles, Racine and others provides a respectful frame for drama while retaining the power of depiction and emotion in sound. It is noteworthy that Jadassohn takes examples from cantatas but rarely mentions opera. In fact, the composers trained in Leipzig tended to write very few exceptional operas or none at all.

Fibich's absolute music adheres to the principles of Jadassohn, but his other works display quite different influences. His copy of the vocal score of Berlioz's opera Benvenuto Cellini bears an annotation that could imply that he knew Harold in Italy as well. ${ }^{4}$ Perhaps he had also heard about that grandest of all grand operas, Les Troyens, shaped by Berlioz's extensive literary knowledge and love for the texts of antiquity. Directly or indirectly, Fibich was following the tradition of Gluck ${ }^{5}$ as it had evolved in the French

2 See Vladimír Hudec, Zdeněk Fibich: tematický katalog [Zdeněk Fibich: Thematic Catalogue] (Prague, 2001).

3 Paul Henry Lang, Music in Western Civilization (New York, 1941), p. 781.

4 Jiří Kopecký, Opery Zdeňka Fibicha z devadesátých let 19. století [The Operas of Zdeněk Fibich from the 1890s] (Olomouc, 2008), p. 41, footnote.

5 Christoforo Gluck, "Alceste" [dedication] in Oliver Strunk, Source Readings in Music History from Classicial Antiquity through the Romantic Era (New York, London, 1950), p. 673-675; here, p. 674-675. "I have striven to restrict music to its true office of serving poetry by means of expression and by following the situations of the story, without interrupting the action or stifling it with a useless superfluity of ornaments; and I believed that it should do this in the same way as telling colors affect a correct and well-ordered drawing, by a well-assorted contrast of light and shade, which serves to animate the figures without altering their contours. Thus I did not wish to arrest an actor in the greatest heat of dialogue in order to wait for a tiresome ritornello, nor to hold him up in the middle of a word on a vowel favorable to his voice... By good fortune my designs were wonderfully furthered by the libretto, in which the celebrated author, devising a new dramatic scheme for florid descriptions, unnatural paragons, and sententious, cold morality, had substituted heartfelt language, strong passions, interesting situations and an endlessly varied spectacle." [translator unknown].

Christoforo Gluck, "lettre de M le Chevalier Gluck, sur le musique", originally published in Mercure de France, February 1773, p. 182; reprinted in Music and Aesthetics in the Eighteenth and Early-Ninettenth Centuries, ed. Peter le Huray and James Day (Cambridge, 1981), p. 148-149; here, p. 149. "I do believe it is possible to say this, however, that I find the most suitable words are those in which the poet has given me the most varied means of expressing the passions. This I believe is the 
heroic and tragic operas that were performed in the Provisional Theatre under Smetana's baton. Their idioms of recitative, vocal expressivity, programmatic reference, as well as expressive modulation and dissonance, surely must have influenced Fibich.

He may also have deliberately transformed some of the techniques discussed in Jadassohn's books for his dramatic works, for example: careful use of rhythm to accentuate expressivity of declamation; depiction of inner thoughts and programmatic elements through subtle changes in repeated accompanying figurations, including chromatic inflection for enhancement and depiction; ${ }^{6}$ the power of the arioso-recitative to express profound emotion; chromaticism and modulation to obtain variety-although Jadassohn says such changes should be used sparingly, so that they do not damage the unity of the work; ${ }^{7}$ the relationship of text and music in melodrama; ${ }^{8}$ development with economy of means-"only a theme, often only a motive or merely a rhythm taken from a motive, provides the material out of which the second [development] section will be built." ${ }^{\text {It }}$ is instructive to study Jadassohn's inspiring, lucid books on music theory and analysis alongside the Fibich operas.

Fibich was one of the first composers to take the path that would lead to modern music: to regard music theory as taught in conservatories as a point of departure rather than as a set of rigorous specifications, to redefine music on his own terms, to express his own creativity freely. But that implied abandoning the fundamental principle of the conservatory tradition, the principle that had enabled him to write large, complex compositions in which form, melody, harmony, and counterpoint are unified to produce a work of intellectual elegance as well as musical beauty. As Jadassohn expressed it, "In music,

advantage that I have found in the text of Iphigéne, the poetry of which has for me all the energy that is necessary to inspire in me good music... With the help of the famous M. Rousseau of Geneva, whom I would propose to consult, we would perhaps-in search of a noble, sensitive and natural melody, and of declamation that exactly matches the prosody of each tongue and the character of the people-be able to determine that way that I have in mind, to produce music that is suited to every nation...” [translator unknown].

6 Salomon Jadassohn discusses the programmatic use of figuration in Schubert's "Gretchen am Spinnerade”, in: Die Formen in den Werken der Tonkunst (Leipzig, 1901), p. 59; for the depiction of the brook's currents and eddies in Schubert's “Ich hört' ein Bächlein rauschen” see ibid., p. 60.

7 Ibid., p. 64, following a discussion of Schubert's "Erlkönig".

8 Jadassohn discusses Schumann's melodrama Manfred in Das Wesen der Melodie in der Tonkunst (Leipzig, 1899), p. $58 \mathrm{ff}$. It is entirely possible that Fibich became acquainted with this work in Leipzig.

9 Jadassohn, Die Formen in den Werken der Tonkunst (Leipzig, 1901), p. 118, discussing the development section of sonata form: "Wenn wir die Durchführungsthile unserer besten Meisterwerke betrachten, so fällte es uns auf, dass durchaus nicht alle Themen und Motiv des ersten Theiles in der Durchführung zur Verwendung kommen, ja dass sogar meist nur ein Thema, oft nur ein Motiv, zuweilen auch nur der Rhythmus eines Motivs der Stoff liefern, aus welchem der zweite Theil gebildet wird. Dieses Thema, oder das ihm entnommene Motiv, pflegt meist das Anfangsthema der Satzes zu sein. So sehen wir des Durchführung im ersten Satze der C-moll-Symphonie von Beethoven virwiegend aus dem motiv gebildet." 
form and content are as intimately bound together as body and soul are in human beings. A musical work without form is as unthinkable as a soul without a body. Music that has an inadequate form is like a soul in an ugly or sickly body. The young artist should not make that error; he should not seek to attain truth of expression at the expense of the beauty and harmony of the musical form." 10

Transforming this principle meant for Fibich-as it later would for Janáček, who also studied in Leipzig, and for Mahler, who trained at the Vienna conservatory-a stylistic metamorphosis as radical as the transformation of Rusalka. And like Rusalka, all three bravely faced the consequences. The plot of Wagner's Die Meistersinger must have shown the way. The rules of music theory have been forced upon music; they are not true to the spirit of music itself. Although Walther disregards the letter of these rules, he is able to preserve their spirit through composing by inspiration. And this example may have given Fibich the necessary creative independence to continue.

Formed by the ideals of early Romanticism, and being a student of Bedřich Smetana, and friend of Ludevít Procházka, it was quite natural that Fibich would devote his musical gifts to Czech nationalism. Musical styles had become a means of making political statements. As Fibich was surely aware, the reviews of the time show that these styles were often publically recognized and labeled in a rather superficial manner. Zdeněk Nejedlý based his discussion of this stage of Fibich's career on a passage from the composer's 1875 review of Ján Levoslav Bella's symphonic poem "Osud a ideál" [Destiny and the Ideal]:"1

How can these obsolete opinions of Lachner, Hiller and others stand against the mighty torrent of titanic ideas of Liszt and Wagner? In our circle, there unfortunately are two sides: those of the 'conservatory' group, who imagine it to be a great event when some of its adherents perform trivial song phrases and forms in the style of Abt and Gumber, and when, out of godlike misery, someone writes a stinking opera in Offenbach's or Gounod's style every three or four years. - The progressive group provides, almost day by day, strong evidence of its vitality in successful compositions from mere songs to great dramatic works, from numerous chamber music compositions to symphonic poems in complex forms.

Bella had studied with Simon Sechter of the Vienna conservatory, a master of theory as internationally respected as Jadassohn was. Fibich may have been referring to reviewers who favored an anti-Wagnerian 'conservatory' style but had little knowledge of what was

$10 \quad$ Ibid., p. 65 [translation by the author]: "In der Musik sind Form und Inhalt so innig mit einander verbunden, wie beim Menschen Körper und Seele. Ein Musikstück ohne Form ist eben so wenig denkbar, als Seele ohne Körper. Musik in ungenügender Form gleicht der Seele im unschönen order siechen Körper. Der Kunstjünger lasse sich daher nicht beirren, er suche nicht die Wahrheit des Ausdruckes auf Kosten der Schönheit und Ebenmassigkeit der musikalischen Form zu erreichen."

11 Zdeněk Fibich, review, Dalibor (1875), p. 151, quoted in Zdeněk Nejedlý, Zdenko Fibich: zakladatel scénického melodramatu [Zdenko Fibich: Founder of Scenic Melodrama] (Prague, 1901) p. 58-59 [translation by the author]. 
actually taught in conservatories. It is entirely possible that Nejedlý misunderstood the passage. He was only in his early twenties when his first work on Fibich was published and may have had little experience of the world outside of his own circle. Nevertheless, Fibich appears to be struggling with the expressive limitations of conservatory techniques in his symphonic poem Othello, composed in 1873.

Fibich met Otakar Hostinský as early as 1871. "Hostinsky, a defender of Bedřich Smetana as the leader of the 'progressive group', was to become Fibich's lifelong friend and adviser." 12 It seems plausible that Fibich's ideas and experience could have affected Hostinský's essay "O hudbě programni”" ["On Program Music”]. This lengthy essay on the controversial subject of program music defines a logically defensible middle way between the diametrically opposed positions of Hanslick and Wagner. Can it be mere coincidence that it devotes much space to the issue of combining the arts? Hostinský frames the problem as follows: a work of art exists naturally in the context of its genre, the conventions of the art in which it was conceived and created. ${ }^{13}$ When it transcends that context, its internal structural and aesthetic properties are affected-perhaps to the point of damaging the intrinsic value of the work of art. Wagner's Gesamtkunstwerk, fusing literature, music, dramaturgy, and the visual arts in the form of opera, was precisely the impetus for much of Hanslick's objections. Hostinsky's response was that each art had a natural boundary within which it was effective, and that combined arts should work in cooperation rather than be sacrificed to the effect of the work as a whole. And this response seems to be reflected in Fibich's dramatic works.

Fibich's remarkable solution begins to emerge with the melodrama Nevěsta messinká. Maria Ottlová credits Hostinský with the idea of a music drama directly based on Classical dramatic recitation. ${ }^{14}$ Hostinský provided Fibich with a libretto based on a play with precisely that sort of text, Friedrich Schiller's tragedy Die Braut von Messina.

Fibich was also influenced by Jaroslav Vrchlický, his librettist for the Hippodamia trilogy and Bouře [The Tempest], ${ }^{15}$ Vrchlický's poems, acknowledged as among the greatest in the Czech language, show a masterful union of profound artistic insight and exquisite form that is often inspired by the highest Classic principles.

Vrchlický was also a prolific translator with an extraordinary knowledge of literature in many countries, traditions, and styles. He endeavored to transfer the poetic structure of the original to Czech, while reconciling the spirit of the work in the original language and its Umdichtung-its poetic effect-not only into the Czech language, but also into the Czech ethos of his time. The literal translation may be altered, the meter of the origi-

12 Jiři Kopecký, Zdeňka Fibicha z devadesátých let 19. století (Olomouc, 2008), especially p. 58-67.

13 Otakar Hostinský, “O hudbě programni”, Dalibor (1873). Reprinted in: Hudební rozhledy [Music Review], 10 (1957), No. 1, p. 9-11; No. 2. p. 53-55; No. 3, p. 98-101; No. 4, p. 142-145; No. 5, p. 186-189; No. 6, p. 239-241.

14 Marta Ottlová, "Jiný svět hudby přelomu století” [Another World of Music at the Turn of the Century], Hudební věda [Musicology], 37 (2000), p. 80.

15 See Jiří Kopecký, Zdeňka Fibicha z devadesátých let 19. století (Olomouc, 2008) for further information about the relationship of Fibich and Vrchlický, especially p. 44-48. 
nal text may not be suitable for Czech, and even the subtext may suffer ${ }^{16}$ However, the translated poem becomes a new work of art that transcends its original context. And that seems to have been Vrchlický's intention as he created the libretto for Boure from Shakespeare's The Tempest.

The natural flow of spoken Czech, even in recitation, did not correspond well to periodic form. ${ }^{17}$ Vrchlický's texts presented additional difficulties, for he was a master of subtle, ingenious meters and stress patterns. Introducing another stylistic factor, such as music, could easily have disrupted their polished artistry. Nevertheless, librettist and composer achieved an excellent working relationship for the opera Boure. ${ }^{18}$

Vrchlickýs example as a translator may have provided the solution, for Fibich took imaginative liberties at times in Boure. He seems to approach the simple rhymed stanza of Ariel's song "Pět stop v hlubi otec lež z kostí jeho korál jest" ["Full fathoms five thy father lies; of his bones are coral made"] as a skilled actor would. He begins by mirroring the stanza form faithfully. But after the second phrase, as Ariel describes the transformation of Fernando/Ferdinand's supposedly drowned father, the musical form is freely transformed as well. And by the end of the song, the imitation of bells gives an impression of spontaneous utterance. Vrchlický goes even further by transforming Shakespeare's poetic intent. The body no longer suffers "a sea-change", fading gently into the sea, for the eyes do not become pearls but stars.

Extended soliloquies with frequent tempo changes emerge naturally from the dramatic current in Boure and Hedy. Particularly interesting is Prospero's farewell to his island and scholarly pursuits, "Tak ostrove můj, sbohem bud'." ["Thus I bid farewell to my island.”]

16 F. X. Šalda seems to have taken particular delight in finding and denouncing these passages. See his reviews "K překladu Baudelairea: kritická studie” [On Translating Baudelaire: a Critical Study], in: Felix Vodička (ed.), F. X. Šalda, Kritické projevy [F. X. Šalda, Essays of Criticism] 2. 1894 (Soubor díla F. X. Šaldy) [Collected Works of F. X. Šalda], Vol. 11 (Prague, n.d.), p. 310-333, and "Edmond Rostand: Cyrano de Bergerac”, in: Rudolf Havel and Karel Jiše (eds.), F. X. Šalda, Kritické projevy 4. 1898-1900 (Soubor díla F. X Šaldy), Vol. 13 (Prague, n.d.) p. 201-208.

17 See Jiř́i Vysloužil, “Ke vztahu slova a tónu a Dvořáka a Janáčka” [On the Relationship of Word and Note in the Music of Dvořák and Janáček], in: Alena Martínková (ed.), Muzikologické rozpravy [Musicological Debates] (Prague, 1986), p. 95-110.

18 Jiři Kopecký, Opery Zdeňka Fibicha z devadesátých let 19. století (Olomouc, 2008), p. 102: “As a result of their collaboration on Hippodamia, the composer had become so close to Vrchlický that he could depend on the poet's willingness to adapt to the logical needs of the music, as long as there was an opportunity to express what he had to say. Both artists could be assured that their solutions were of equal importance and that they could reach agreement. Most of all, Vrchlický and Fibich were close friends, and Fibich was able to inspire the poet. Fibich achieved an exceptional capability with the spoken word and expertise in adapting the relationship of the musical accompaniment to specific areas of the text and dramatic action, ranging: from simple supporting chords to the development of characteristic motives; from consistent duple meters and periods to relatively independent musical passages (particularly in monologues) and march interludes; and to giving entire scenes a consistent shape using their tempo, mood, and passion as well as their place in the form of the play. Fibich found a way to make a flexible connection between music and the strict declamation of each word, thus providing better support for correct declamation.” 
Shakespeare's soliloquy has been expanded by Vrchlický into such a remarkable character study that it could well be a self-portrait. Hedy's and Juan's soliloquies are so extensive, so intimate, that they overshadow the lovers' only duet. These soliloquies surely have a kinship to the multi-tempo arias of the early Romantic era, expressing the inner, evolving thoughts of the singer, notably Agatha's "Leise, leise” from Weber's Der Freischütz. They anticipate, for example, Kostelnička's expressionistic scene "Co chvíla" ["What a moment”] in Janáček’s Jenůfa, and Marie's confessional scene "Herr Gott, Herr Gott! Sieh mich nicht an!” in Berg's Wozzeck.

The dramatic scene, the contemplative poetic strophe or set of strophes, and the instrumental interlude depicting the theatrical moment have become units of form. The recitative is transformed to become a strong unifying factor: the music responds precisely and flexibly to the text with a rich tapestry of nuance, rhythmic accent, figuration, and gesture. The result resembles the textures that will pervade twentieth-century avant-garde orchestral music.

Although Fibich's operas do show Wagnerian influence, they differ from Wagner's mature style in several important respects. Perhaps the most obvious difference has to do with the way that drama and music are combined. Wagner's mature operas are throughcomposed, the music fused with the current of dramatic action, subjugating all aspects of music to the effect of the work as a whole. Fibich's entirely different approach reveals his unusual musical insight as well as his independent nature. Dramatic form and content provide the backbone for musical form and content, especially in the Hippodamia trilogy. Then melody, harmony, and counterpoint can develop independently within the dramatic context. This truly original process would allow Fibich to set the dramatic work like a jewel in the precious metal of music, to be faithful to the text while achieving musical effectiveness in performance.

Fibich's characteristic motifs are linked to the characters of the drama, but they have a more sophistical role than Wagnerian leitmotifs do. Rather than serving as an obvious guide for the listener, they are subtly woven into the accompaniment to provide support for the subtext. Their transformations reflect the state of the character and his or her context at a given moment. Unlike the early modernists, he is able to build forms completely at will, and still retain the full power of tonality.

As the bearer of the psychological and dramatic subtext, the large form becomes the unifying frame for the soliloquies, scenes, songs, events, and portrayals of moods that comprise the opera. Material from motifs, figurations, and patterns can now be used interchangeably to command attention, strengthen structural coherence, support the subtle inflections of the plot, and provide programmatic reference. Fibich had used figurations for elaborate programmatic depiction as early as Nevěsta messinká. Donna Isabella's aria about her husband's prophetic dream, "Vám útlý mladí věk již kalil spor" ["The tender days of your youth are already marred with conflict"], contains a brief passage "Tu náhle bílá lilie" ["The white lilies"]. She describes white lilies growing among the laurels that sprouted from her marriage bed. As the lilies burst into fire, the accompaniment expertly portrays, word by word, the gentle flowers and then the sudden, devouring flames leaping 
to the massive laurel trees and destroying the castle itself. More sophisticated means of depiction are possible in Boure and the operas that follow it. The game of chess played by Fernando and Miranda is mirrored by structural patterns. Structural depiction appears in other compositional factors as well. After Hedy and Juan part, an instrumental interlude dissolves into pointless modulations as the lovers grieve.

The unifying frame of the large form enables Fibich to imbed smaller forms in ingenious ways, as Berg would later do in his opera Wozzeck. For example, the first verse of Vlasta's well-known "Slyšte, věční prosby hlas" ["Hear our voice in eternal prayer"] in Šárka is a closed period. But the second verse begins with a period-like structure that is transformed to introduce an entirely different dramatic situation. The interplay between large and small form is even more remarkable in the coda that ends Hedy, "Zde můj život vzešel, a zde také skonči!" ${ }^{19}$ The text is like that of Wagner's "Liebestod": "Here my life began; here it also ends. Gently open now thy arms to me, sweet death." Again like "Liebestod", Fibich's melody is successively transposed at the interval of the minor third, outlining the diminished seventh chord that had opened the French operatic style to dissonance, but forming a closed, complete extended period. All twelve notes of the chromatic scale appear in these transpositions, providing closure for the luxuriant, passionate chromaticism that pervades the opera, the great love that it represents, and the opera as a whole. This pedestal of form gives classic nobility to Hedy's final words.

Dargun, unfortunately Fibich's last opera, is stripped of everything that is not essential to the dramatic moment. Although its effect is strikingly like that of Nevěsta messinká, it displays new fluency and assurance, a sense that Fibich has definitively surpassed his master. The combination of melody, harmony, and rhythm has been superseded by a combination of timbre, nuance, dynamics, voicing, and motif which seems related to Janáček's concept of nápěvek mluvy [speech melody]. However, this new combination also gives expressive individuality to isolated notes and chords. Another trait usually ascribed to Janáček comes to prominence in this opera: the pitch outline of the expressively spoken phrase is meticulously reflected in the pitch outline of its musical setting. Fibich generally intensifies this effect through chromatic inflection-much like the "blue notes" of American jazz-rather than selecting pitches that are awkward within the harmonic context. But Dargun is a pagan, and the rough atonality of his vocal lines depicts his character.

These techniques liberate pitch from traditional constraints of melody and harmony. Fibich imbeds dodecaphonic passages skilfully, almost casually, into the dramatic flow. With Radana's macabre "Ty chladné rty už líbat nemohu" ["I cannot kiss your cold lips any more"] he momentarily crosses the boundary into twentieth-century expressionism. As a result of progressively more daring expansions of conventional harmony, through expressive chromatic embellishment as well as deliberately shocking portrayals of terrifying dramatic moments, he has discovered useful ways to harness atonality.

Dargun ends in consonance with the victorious, spiritually uplifting music of Absolon. Beauty and noble elegance have finally triumphed over tragedy; Fibich's pilgrimage has

19 This example is given ibid., p. 184. 
reached a fitting destination. But his journey has produced many remarkable ideas for the future.

\title{
„I Fear not Wave nor Wind“: Das Charakter des Weges Fibichs zur modernen Musik
}

\section{Zusammenfassung}

Die Musik Fibichs spiegelt sein lebenslanges Suchen nach Schönheit, dramatischer Darstellung und jener klassischen Proportionalität wider, wie sie zu seiner Zeit verstanden wurde. Indem er diese Prinzipien weiterentwickelte, um seinen Stil in den dramatischen Werken zu gestalten, ist er bis an die Schwelle der Moderne gelangt. Zu den Innovationen Fibichs gehören: der Ausbau von breiten, auf dem dramatischen Verlauf beruhenden Formen, innerhalb derer sich die Harmonik, Melodik und thematischen Strukturen frei entfalten können; ausgedehnte, nach dem Vorbild von Arien mit verschiedenem Tempowechsel beruhende dramatische Monologe; Strukturen, deren Zusammenhalt von der wechselseitigen Verflechtung der musikalischen, nur auf ihre theatralische Wirkung hin berechneten Vorgänge abhängt; geschickte Verwendung der Kleinformen im Rahmen der großen Formen, charakteristische Motive und Figurationen, die auf den Verlauf der Handlung reagieren; ebenso programmatische Illustrationen, chromatische Verdichtungen und sich der Atonalität annähernde Rezitative. In seiner letzten Oper Dargun ist Fibich bis zu dodekaphonischen Atonalität selbst gelangt.

Übersetzt von Vlasta Reittererová

\section{„I Fear not Wave nor Wind“": charakter Fibichovy cesty k moderní hudbě}

\author{
Shrnutí
}

Fibichova hudba odhaluje celoživotní hledání krásy, dramatického zobrazení a klasické vyváženosti tak, jak byly tyto kvality chápány v jeho době. Zatímco rozvíjel tyto principy, aby zformoval kompoziční styl svých dramatických děl, stanul na prahu moderny. Mezi Fibichovy inovace patří: formování rozsáhlých ploch založených na dramatickém proudu, ve kterém se volně rozvíjejí harmonie, melodie a tematické vazby; široce založené dramatické monology modelované podle vzoru vícetempových árií; struktury, jejichž soudržnost se opírá o vzájemnou propojenost hudebních událostí, vybraných pouze pro divadelní účinek; důvtipné použití malých forem $\mathrm{v}$ rámci velkých, příznačné motivy a figurace, reagující na změny děje; programní popisy, chromatické zahuštování a recitativy, bližící se atonalitě. V poslední opeře Dargun Fibich dospěl až k dodekafonicky pojaté atonalitě. 


\section{Keywords}

Salomon Jadassohn; Jaroslav Vrchlický; Zdeněk Fibich; modernism. 